\title{
PROFESIONALITAS APARATUR SIPIL NEGARA DALAM PELAYANAN PUBLIK PADA DINAS KEPENDUDUKAN DAN PENCATATAN SIPIL KABUPATEN KEPULAUAN SANGIHE
}

\author{
Megawati Hardiana Messe, Itje Pangkey \\ Program Studi Ilmu Administrasi Negara FIS Unima \\ Emal: itjepangkey@unima.ac.id.
}

\begin{abstract}
ABSTRAK
Penelitian ini bertujuan untuk menganalisis profesionalitas aparatur sipil negara dalam pelayanan publik di Dinas Kependudukan dan Pencatatan Sipil Kabupaten Kepulauan Sangihe. Penelitian ini tergolong adalah metode penelitian deskriptif dengan pendekatan kualitatif, yang mengambarkan bagaimana situasi sebagaimana memahami fenomena-fenomena tentang Profesionalitas Aparatur Sipil Negara Dalam Pelayanan Publik di Dinas Kependududukan dan Pencactatan Sipil Kabupaten Kepulauan Sangihe. Penelitian ini menggunakan jenis penelitian deskriptif dengan pisau analisis Sobandi (2002:64) yang menyebutkan bahwa profesionalitas adalah suatu tingkah laku atau suatu tujuan atau rangkaian kualitas yang menandai atau melukiskan coraknya atau profesi berdasarkan aturan atau kemampuan kompetensi dari seseorang alam bertindak dan bertingkah laku sesuai dengan profesi berdasarkan aturan, yang ditentukan dari: (1) Ahli (Expertise); (2) Mandiri (Autonomy); (3) Tanggung jawab (Responsibilty). Hasil penelitian menunjukkan bahwa: 1) pekerjaan selalu terhalangi dengan kurangnya pegawai, 2) dokumen masyarakat belum lengkap, 3) pegawai yang bekerja sebagian belum sesuai dengan kompetensi tetapi hanya berdasarkan pengalaman kerja 4) saat tertentu terdapat sikap kompromi yang berdampak pada hasil kerja belum sesuai dengan apa yang diharapkan. Untuk itu disarankan sebaiknya 1) Dilakukan perbaikan kualitas Sumber Daya Manusia, 2).pengadaan sarana prasarana untuk kepentingan pelayanan, 3).sosialisasi kepada masyarakat mengenai kelengkapan administrasi kependudukan yang harus disiapkan oleh masyarakat, 4). ditingkatkan kemandirian 5). ditingkatkan tanggung jawab ASN.
\end{abstract}

\section{Kata Kunci : Profesionalitas Aparatur Sipil Negara, DUKCAPIL}

\section{PENDAHULUAN}

Aparat pemerintah memegang peran yang sangat penting dan strategis dalam hal pelaksanaan pemerintahan dapat berjalan dengan efektif dan efisien, dituntut tersedianya aparat pemerintah yang profesional serta diharapkan dapat menjadi teladan bagi masyarakat lainnya. Untuk mendapatkan aparat yang profesional tersebut diperlukan kualitas sumber daya aparatur yang sesuai dengan tuntutan organisasi. Pelayanan Publik oleh Aparatur Pemerintah dewasa ini masih banyak dijumpai kelemahan sehingga belum dapat memenuhi kualitas yang diharapkan masyarakat. Mengingat fungsi utama pemerintah adalah melayani masyarakat maka pemerintah perlu terus berupaya meningkatkan kualitas pelayanan.

Upaya untuk mewujudkan penyelenggaraan Pemerintahan secara benar termasuk didalamnya penyelenggaraan pelayanan publik memerlukan unsur-unsur mendasar antara lain adalah unsur profesionalitas dari pelaku dan penyelenggara pemerintahan dan pelayanan publik. Terabaikannya unsur profesionalitas dalam menjalankan tugas dan fungsi organisasi pemerintahan akan berdampak kepada menurunnya kualitas penyelenggaraan pemerintahan dan pelayanan publik. Sehingga aparatur dituntut untuk memiliki kemampuan dan keahlian untuk memahami aspirasi dan kebutuhan masyarakat kedalam kegiatan dan program pelayanan. 
Dalam Undang-Undang No 5 Tahun 2014 tentang Aparatur Sipil Negara menyebutkan bahwa dalam rangka pelaksanaan cita-cita bangsa dan mewujudkan tujuan negara sebagaimana tercantum dalam pembukaan Undang-Undang Dasar Negara Republik Indonesia Tahun 1945, perlu dibangun Aparatur Sipil Negara yang memiliki integritas, profesional, netral, dan bebas dari intervensi politik, bersih dari praktik korupsi, kolusi dan nepotisme, serta mampu menjalankan peran sebagai unsur perekat persatuan dan kesatuan bangsa berdasarkan Pancasila dan Undang-Undang Dasar Negara Republik Indonesia Tahun 1945.

Di era reformasi saaat ini maka dituntut perbaikan di segala aspek, sehingga masyarakat menuntut terwujudnya aparatur pemerintah yang lebih profesional dan kompeten yang merupakan dasar penciptaan organisasi yang baik, dan juga perubahan sikap dan perilaku agar dapat melayani masyarakat dengan baik dikarenakan perubahan-perubahan sosial di masyarakat menjadi lebih sadar akan haknya sebagai warga negara untuk mendapatkan pelayanan yang baik dan berkualitas dari pemerintah. Pentingnya Profesionalitas aparatur pemerintah sejalan dengan bunyi pasal 3 Undang-Undang Nomor 43 Tahun 1999 tentang perubahan atas Undang-undang Nomor 8 Tahun 1974 tentang Pokok-Pokok Kepegawaian yang menyatakan bahwa "Pegawai negeri berkedudukan sebagai unsur aparatur negara yang bertugas untuk memberikan pelayanan secara profesional, jujur, adil, dan merata dalam penyelenggaraan tugas negara, pemerintah dan pembangunan.

Dinas Kependudukan dan Pencatatan Sipil Kabupaten Kepulauan Sangihe sebagai institusi yang menjalankan fungsi pelayanan Publik kepada masyarakat di bidang kependudukan dalam menjalankan tugas pokoknya memiliki permasalahan berdasarkan yang saya teliti yaitu Belum optimalnya kualitas SDM, Belum maksimalnya sarana dan prasarana pendukung dalam penerbitan dokumen kependudukan dan pencatatan sipil, Jaringan belum stabil, belum representatifnya ruang pelayanan/gedung kantor. permasalahan-permasalahan diatas maka penulis tertarik untuk meneliti lebih lanjut tentang "Profesionalitas Aparatur Sipil Negara Dalam Pelayanan Publik Pada Dinas Kependudukan dan Pencatatan Sipil Kabupaten Kepulauan Sangihe".

\section{TINJAUAN PUSTAKA Pelayanan Publik}

Istilah pelayanan publik (publik service) di Indonesia memiliki arti yang sama dengan istilah pelayanan umum atau pelayanan masyarakat secara luas. Oleh karena itu ketiga istilah ini digunakan bersamaan dan tidak mempunyai perbedaaan arti yang mendasar. Pelayanan yang memiliki fungsi sebagai satu sistem yang menyediakan apa yang masyarakat butuhkan saat ini.

Dalam hal ini, pelayanan publik merujuk pada pengertian masyarakat atau umum. Namun demikian pengertian publik yang melekat pada pelayanan publik tidak sepenuhnya sama dengan pengertian masyarakat. Pelayanan publik dapat diartikan sebagai pemberian layanan (melayani) keperluan orang atau masyarakat yang mempunyai kepentingan pada organisasi itu sesuai dengan aturan pokok dan tata cara yang telah ditetapkan.

$$
\text { Menurut Kepmen PAN }
$$

No.63/KEP/M.PAN/7/2003 Pelayanan publik adalah segala kegiatan pelayanan yang dilaksanakan oleh penyelenggaran pelayanan publik sebagai upaya pemenuhan kebutuhan penerima pelayanan maupun pelaksanaan ketentuan peraturan. Berdasarkan beberapa pengertian diatas maka dapat ditarik kesimpulan bahwa yang dimaksud dengan pelayanan publik adalah segala bentuk pelayanan yang dilakukan oleh suatu organisasi atau badan tertentu yang bertujuan untuk memenuhi kepentingan masyarakat guna mencapai kepuasan sebagai pelaksanaan ketentuan atau kewajiban dari badan yang telah diatur dalam suatu peraturan Perundang-undangan. Dengan demikian pelayanan publik dapat dilakukan oleh instansi pemerintah, swasta, baik dipusat maupun daerah dalam rangka memenuhi kebutuhan masyarakat.

Pelayanan publik biasanya dilakukan oleh birokrat atau pejabat pemerintahan merupakan perwujudan dari fungsi aparatur negara sebagai abdi masyarakat di samping sebagai abdi 
negara. Pemerintahan pada hakikatnya memberikan pelayanan kepada masyarakat. Pemerintahan adalah diadakan untuk melayani masyarakat serta menciptakan kondisi yang memungkinkan setiap anggota masyarakat mengembangkan kemampuan dan kreativitasnya demi mencapai tujuan bersama (Rasyid, 1998).

Pelayanan publik menjadi suatu tolak ukur kinerja pemerintah yng paling kasat mata. Masyarakat dapat langsung menilai kinerja pemerintahan berdasarkan kulaitas pelayanan publik yang diterima, karena kualitas layanan publik menjadi kepentingan banyak orang dan dampaknya langsung dirasakan masyarakat dari semua alangan, dimana keberhasilan dalam membangun kinerja pelayanan publik secara profesional efektif, efisien dan akuntabel akan mengangkat citra positif pemerintah di mata warga masyarakatnya.

Menurut Agung Kurniawan 2005 mengatakan bahwa pelayanan publik adalah pemberian pelayanan (melayani) keperluan orang lain atau masyarakat yang mempunyai kepentingan pada organisasi itu sesuai dengan aturan pokok dan tata cara yang telah ditetapkan (dalam Pasolong 2010-128). Berdasarkan Undang-Undang Nomor 25 Tahun 2009 tentang pelayanan publik pasal 1 ayat 7 , standar layanan adalah tolak ukur yang dipergunakan sebagai pedoman penyelenggaraan layanan dan acuan penilaian kualitas pelayanan sebagai kewajiban dan janji penyelenggara kepada masyarakat dalam rangka pelayanan yang berkualitas, cepat, mudah, terjangkau dan terukur.

Dalam memberikan pelayanan publik, instansi penyediaan pelayanan harus memperhatikan asas pelayanan publik. Asas pelayanan publik menurut Keputusan Menpan 63/2003 sebagai berikut :

1. Transparansi, bersifat terbuka, mudah dan dapat diakses oleh semua pihak, disediakan secara memadai dan mudah dimengerti.

2. Akuntabilitas, dapat dipertanggungjawabkan sesuai dengan ketentuan peraturan perundang-undangan.

3. Kondisional, sesuai dengan kondisi dan kemampuan pemberi dan penerima pelayanan dengan tetap berpegang pada prinsip-prinsip efisiensi dan efektivitas.

4. Partisipasi, mendorong peran serta masyarakat dalam penyelenggaraan pelayanan publik dengan memperhatikan aspirasi, kebutuhan, dan harapan masyarakat.

\section{Aparatur Sipil Negara}

Pengertian mengenai ASN itu sendiri tertuang pada pasal 1 angka 1 UU No. 5 tahun 2014 yang menyebutkan bahwa ASN adalah profesi bagi PNS dan PPPK yang bekerja pada instansi pemerintah. PNS menurut Kamus Umum Bahasa Indonesia, adalah orang yang bekerja untuk pemerintah atau negara. Menurut Kranenburg PNS adalah pejabat yang ditunjuk, jadi pengertian tersebut tidak termasuk terhadap mereka yang memangku jabatan mewakili seperti anggota parlemen, presiden dan sebagainnya.

Berdasarkan beberapa pengertian tersebut dapat disimpulkan bahwa PNS adalah orangorang yang bekerja di lingkungan instansi pemerintahan sesuai dengan syarat-syarat tertentu yang telah ditetapkan oleh peraturan perundang-undangan. Sesuai dengan UU No. 5 tahun 2014.

\section{Jenis, Status, dan Kedudukan Aparatur Sipil Negara}

1. Jenis ASN

Mengenai jenis pegawai ASN diatur pada pasal 6 UU No. 5 tahun 2014. Dimana pegawai ASN terdiri atas PNS dan PPPK.

2. Status ASN

Berbicara mengenai status pegawai ASN, terdapat dua status yang diberlakukan bagi pegawai ASN yaitu pegawai pemerintah yang diangkat sebagai pegawai tetap yaitu PNS dan pegawai pemerintah dengan perjanjian kerja

Mengenai status ASN diatur pada pasal 7 ayat (1) dan ayat (2) UU No. 5 tahun 2014 yang menyatakan bahwa :

1) PNS sebagaimana dimaksud dalam Pasal 6 huruf a merupakan Pegawai ASN yang diangkat sebagai pegawai tetap oleh Pejabat pembina kepegawaian dan memiliki nomor induk pegawai secara nasional. 
2) PPPK sebagaimana dimaksud dalam Pasal 6 huruf $b$ merupakan Pegawai ASN yang diangkat sebagai pegawai dengan perjanjian kerja oleh Pejabat pembina kepegawaian sesuai dengan kebutuhan Instansi Pemerintah dan ketentuan Undang-Undang ini.

3. Kedudukan

Rumusan kedudukan pegawai ASN didasarkan pada pokok-pokok pikiran bahwa pemerintah tidak hanya menjalankan fungsi umum pemerintahan, tetapi juga harus mampu melaksanakan fungsi pembangunan atau dengan kata lain pemerintah bukan hanya menyelenggarakan tertib pemerintahan, tetapi juga harus mampu menggerakan dan memperlancar pembangunan untuk kepentingan rakyat banyak.

Pegawai ASN mempunyai peran yang amat sangat penting sebab pegawai ASN merupakan unsur dari aparatur negara untuk menyelenggarakan, dan melaksanakan pemerintahan serta pembangunan nasional dalam rangka mencapai tujuan negara. Kelancaran dari penyelengaraan dan pelaksanaan pemerintahan serta pembangunan nasional dalam rangka mencapai tujuan negara sangat tergantung sekali pada kesempurnaan aparatur negara.

\section{Fungsi, Tugas, dan Peran Aparatur Sipil Negara}

Berdasarkan UU No. 5 tahun 2014, Fungsi, Tugas, dan Peran dari ASN diatur dalam BAB IV pasal 10, pasal 11, dam pasal 12. Yaitu sebagai berikut : Berdasarkan pada pasal 10 pegawai ASN memiliki fungsi sebagai pelaksana kebijakan publik, pelayan publik, dan perekat dan pemersatu bangsa.

a. Berdasarkan pada pasal 11 pegawai ASN mempunyai tugas untuk melaksanakan kebijakan publik yang dibuat oleh pejabat pembina kepegawaian sesuai dengan ketentuan peraturan perundang-undangan, memberikan pelayanan publik yang profesional dan berkualitas, dan mempererat persatuan dan kesatuan dari Negara Kesatuan Republik Indonesia.

b. Berdasarkan Pasal 12 peran dari pegawai ASN adalah sebagai perencana, pelaksana, dan pengawas penyelenggaraan tugas umum pemerintahan dan pembangunan nasional melalui pelaksanaan kebijakan dan pelayanan publik yang profesional, bebas dari intervensi politik, serta bersih dari praktik KKN.

\section{Karakteristik dari Profesionalitas}

Istilah profesionalitas berasal dari kata professio, dalam Bahasa Inggris profession memiliki arti sebagai berikut : A vocation or occupation requiring advanced training in some liberal art or science and usually involving mental rather than manual work, as teaching engineering, writing, etc. (Webster dictionary, 1960:1163). Dari kata profesional tersebut melahirkan arti profesional, quality, status,,dll yang secara komperhensif memiliki arti lapangan kerja tertentu yang dimiliki oleh orang-orang yang memiliki kemampuan tertentu pula sebagaiamna yang dikatakan pamudji, 1985 (Sembang, Riski 2016:30).

Perbedaan antara profesi, profesionalitas, profesionalisme, dan profesionalitas menurut kamus besar bahasa indonesia edisi ketiga dapat dibedakan sebagai berikut : profesi ialah bidang pekerjaan yang dilandasi pendidikan keahlian (keterampilan, kejujuran, dsb) tertentu. Profesional ialah a) bersangkutan dengan profesi, b) memerlukan kepandaian khusus untuk menjalankannya, c) mengharuskan adanya pembayaran untuk melakukanya. Profesionalisme ialah mutu, kualitas, dan tidak tanduk yang merupakan ciri suatu profesi atau orang yang profesional. Profesionalitas ialah a) perihal profesi, b) keprofesian, c) kemampuan untuk betindak secara profesional. (Arifin, 2012:110).

Sobandi (2002:64) menegaskan bahwa "profesionalitas Birokrasi adalah suatu tingkah laku, suatu tujuan atau rangkaian kualitas yang menandai atau melukiskan coraknya suatu profesi yang dimiliki oleh birokrat dalam melaksanakan pekerjaan". Lebih jauh Sobandi (2002:64) mengemukakan bahwa ada beberapa karateristik dari profesionalitas birokrasi yaitu yang pertama, harus ahli (expertise); bahwa pegawai harus menguasai pekerjaan, menguasai tugas dan memahami permasalahan. Karena ketika pegawai tidak tahu dan tidak menguasai suatu pekerjaan yang dibebankan kepadanya 
makanya pekerjaan itu akan tidak maksimal kinerjanya apabila dikerjakan yang bersangkutan. Kedua, yaitu mampu mandiri (autonomy); dimaksudkan pegawai tidak boleh ada ketergantungan. Mempunyai pendirian dan mampu berdiri sendiri. Pegawai tersebut harus mampu memposisikan diri dan tidak terbawa arus disaaat waktu-waktu tertentu. Yang ketiga yaitu bertanggung jawab terhadap segala sesuatu yang dikerjakan. Profesionalitas pegawai yang ada pada birokrasi dalam bekerja yang terdapat pada suatuu organisasi birokrasi dalam menguraikan kerangka kerjanya merupakan salah satu faktor yang penting untuk mencapai kinerja pegawai sebuah organisasi. Kebutuhan seseorang berbeda satu dengan lainnya, sehingga nilai intensitas kebutuhan akan berbeda-beda. Jika kebutuhan adalah salah satu faktor penyebab yang mendasari terjadinya perilaku seseorang, maka bisa dikatakan bahwa kebutuhan yang paling kuat pada saat tertentu akan terlihat seperti daya pendorong yang membuat seseorang untuk berperilaku kearah tercapainya tujuan.

Profesionalitas tidak hanya berbicara tentang soal kecocokan antara keahlian dan kemampuan yang dimiliki oleh seseorang saja tetapi juga menyangkut kemampuan dalam mengantisipasi segala perubahan lingkungan termasuk kemampuan dalam merespons aspirasi publik dan melakukan inovasi yang pada akhirnya membuat pekerjaan menjadi mudah dan sederhana berdasarkan aturan. Profesionalitas merupakan sesuatu yang digunakan dalam menilai kualitas kerja seseorang berdasarkan aturan. Apakah seseorang itu bekerja dengan profesional atau bekerja dengan menggunakan perasaan pribadi. Profesionalitas menurut Sobandi (2002:64) adalah suatu tingkah laku atau suatu tujuan atau rangkaian kualitas yang menandai atau melukiskan coraknya atau profesi berdasarkan aturan. Hal ini berarti profesionalitas adalah kemampuan kompetensi dari seseorang dalam bertindak dan bertingkah laku sesuai dengan profesi berdasarkan aturan. Pandangan lain seperti (Siagian,2002:163) menyatakan bahwa yang dimaksud dengan profesionalitas adalah merupakan kehandalan dalam pelaksanaan tugas sehingga terlaksana dengan mutu tinggi, waktu yang tepat, cermat dan dengan prosedur yang mudah dipahami dan di ikuti oleh stakeholder. Terbentuknya aparatur profesional memerlukan pengetahuan dan ketrampilan khusus yang dimiliki oleh aparat memungkinkannya untuk menjalankan tugas dan menyelenggarakan pelayanan publik dengan mutu tinggi, tepat waktu, dan prosedur yang sederhana. Terbentuknya kemampuan dan keahlian juga harus diikuti dengan perubahan iklim dalam dunia birokrasi yang cenderung bersifat kaku dan tidak fleksibel. Sudah menjadi kebutuhan mendesak bagi aparat untuk bekerja secara profesional serta mampu merespon perkembangan global dan aspirasi masyarakat dengan mengedepankan nilai-nilai pelayanan yang responsif, inovatif, efektif dan mengacu pada kepada visi dan nilai-nilai organisasi. Fleksibilitas aparat dalam menjalankan tugas dan berorientasi kepada hasil dan visi yang ingin dicapai oleh organisasi merupakan langkah positif untuk meninggalkan cara kerja yang kaku dan reaktif.

Orang yang bekerja secara profesional hendaknya mampu dan mempunyai rasa tanggung jawab yang dipercayakan kepadanya baik yang berbentuk tanggung jawab pribadi, sosial, inteleektual maupun tanggung jawab moral sehinnga didalam lingkungan pekerjaan profesionalisme menjadi tolak ukur dimana pegawai yang profesional akan menciptakan kreativitas baru.

\section{METODE PENELITIAN}

Penelitian ini tergolong adalah metode penelitian deskriptif dengan pendekatan kualitatif, yang mengambarkan bagaimana situasi sebagaimana memahami fenomenafenomena tentang Profesionalitas Aparatur Sipil Negara Dalam Pelayanan Publik di Dinas Kependududukan dan Pencactatan Sipil Kabupaten Kepulauan Sangihe.

Dalam penelitian kualitatif, proses pengumpulan data ini meliputi tahap-tahap sebagai berikut:

1. Proses memasuki lokasi penelitian

2. Ketika berada di lokasi penelitian

3. Mengumpulkan data:
a) Wawancara,
b) Observasi 
c) Dokumentasi

Dalam penelitian kualitatif, analis data dilakukan sejak awal sepanjang proses penelitian berlangsung. Dalam penelitian ini digunakan analisis data penelitian kualitatif model interaktif (Miles dan Huberman, 1992 : 112) dengan tahap: reduksi data, penyajian data, menarik kesimpulan atau verifikasi

\section{HASIL DAN PEMBAHASAN}

Profesionalitas Aparatur Sipil Negara Dalam Pelayanan Publik Di Dinas Kependudukan dan Pencatatan Sipil Kabupaten Kepulauan Sangihe.

Salah satu kegiatan pelayanan pemerintah yang memiliki intensitas pelayanan kepada masyarakat yang cukup tinggi adalah pelayanan di bidang administrasi kependudukan di Dinas Kependudukan dan Pencatatan Sipil. Intensitas pelayanan ini adalah berkaitan dengan cara kerja aparatur sipil negara dalam meningkatkan pelayanan administrasi kependudukan di Dinas Kependudukan dan Pencatatan Sipil. UndangUndang Nomor 24 Tahun 2013 tentang perubahan atas Undang-Undang Nomor 23 Tahun 2006 tentang administrasi kependudukan menjelaskan bahwa Dinas Kependudukan dan Pencatatan Sipil bertugas untuk menangani bidang pelayanan administrasi kependudukan dan menjadi satu-satunya instansi yang dapat menerbitkan dokumen kependudukan. Sangat banyak dokumen resmi yang harus dimiliki Warga masyarakat sebagai bukti Warga Negara Indonesia. Semuanya harus berurusan dengan Dinas Kependudukan dan Pencatatan Sipil. Kerja Aparatur Sipil Negara yang prima dibutuhkan untuk bisa menerapkan programprogram pemerintah yang ada secara profesional. Selain itu, kerja Aparatur Sipil Negara yang Profesional juga diharapkan dapat meningkatkan pelayanan yang ada.

Untuk menilai seseorang bekerja profesional dalam pekerjaannya bisa dinilai dari beberapa indikator seperti: Ahli (expertise); Mandiri (Autonomy); dan Bertanggung jawab dalam pekerjaannya (Responsibility).

Profesionalitas menurut Sobandi (2002:64) adalah suatu tingkah laku atau suatu tujuan atau rangkaian kualitas yang menandai atau melukiskan coraknya atau profesi berdasarkan aturan. Hal ini berarti profesionalitas adalah kemampuan kompetensi dari seseorang dalam bertindak dan bertingkah laku sesuai dengan profesi berdasarkan aturan. Profesionalitas tidak hanya berbicara tentang soal kecocokan antara keahlian dan kemampuan yang dimiliki oleh seseorang saja tetapi juga menyangkut kemampuan dalam mengantisipasi segala perubahan lingkungan termasuk kemampuan dalam merespons aspirasi publik dan melakukan inovasi yang pada akhirnya membuat pekerjaan menjadi mudah dan sederhana berdasarkan aturan. Profesionalitas merupakan sesuatu yang digunakan dalam menilai kualitas kerja seseorang berdasarkan aturan. Apakah seseorang itu bekerja dengan profesional atau bekerja dengan menggunakan perasaan pribadi.

Berbicara keahlian (Expertise) bahwa pegawai harus menguasai pekerjaan, menguasai tugas dan memahami permasalahan. Karena ketika pegawai tidak tahu dan tidak menguasai suatu pekerjaan yang dibebankan kepadanya makanya pekerjaan itu akan tidak maksimal kinerjanya apabila dikerjakan yang bersangkutan. Yang menjadi permasalahan adalah ketika sebagian staff/pegawai yang ada di Dinas Kependudukan dan Pencatatan Sipil Kabupaten Kepulauan Sangihe bekerja diluar tugas pokok dan fungsi mereka karena pada dasarnya semua ASN sudah profesional, namun dikarenakan pekerjaan yang ada selalu terhalangi dengan kurangnya pegawai, jaringan yang tidak stabil, dan dokumen dari masyarakat yang belum lengkap, maka hasil kerja belum sesuai dengan apa yang diharapkan dan Pegawai yang bekerja sebagian besar belum sesuai dengan kompetensinya/ posisinya namun hanya berdasarkan pengalaman saja. Secara tidak langsung, hasil kerja yang mereka hasilkan masih belum maksimal. SDM adalah jantungnya organisasi. Organisasi yang besar sangat membutuhkan banyak pegawai sebagai penopang keberhasilan satuan kerja.

Pegawai yang mampu mandiri (Autonomy) adalah seorang pegawai yang bisa melaksanakan tugasnya dengan sangat profesional. Karena ketika ASN itu bekerja mandiri, dia akan bekerja sesuai dengan keahliannya dan tanpa menunggu orang lain 
atau atasannya untuk bekerja. Kemandirian harus ada pada diri setiap pegawai. Karena Kemandirian merupakan sebuah kunci Kesuksesan seorang pegawai dalam bekerja. Temuan di lokasi penelitian adalah Pegawai sudah melaksanakan pekerjaan dengan mandiri tanpa menunggu perintah atasan.

$$
\text { Berbicara tanggung jawab }
$$

(Responsibility) tentunya akan berbicara mengenai tugas pokok dan fungsi seorang dalam menjalankan tugasnya. Berdasarkan Peraturan Bupati Kepulauan Sangihe Nomor 54 tahun 2016 tentang Kedudukan, Susunan Organisasi, Tugas dan Fungsi Serta Tata Kerja Dinas Kependudukan dan Pencatatan Sipil Kabupaten Kepulauan Sangihe dengan sangat jelas mengatur tentang tugas pokok dan fungsi bagi setiap pegawai yang ada di dinas tersebut. Prosedur yang ada juga sangat berpengaruh dalam tercapainya profesionalitas kerja pegawai. Karena ketika seorang pegawai bekerja apabila tidak mengikuti pedoman/petunjuk pelaksanaan pekerjaan maka akan segera langsung bekerja tidak sesuai dengan apa yang di harapkan. Bekerja tanpa arah dan tujuan dan tentunya juga menghambat pekerjaan selanjutnya yang belum dikerjakan.

Temuan di lokasi penelitian adalah Belum sesuai SOP karena pada saat-saat tertentu ada sikap kompromi satu sama lainnya seperti dalam hal proses administrasi di kantor. Capaian kinerja yang diperoleh Dinas Kependudukan dan Pencatatan Sipil Kabupaten Kepulauan Sangihe belumlah mencapai hasil yang mengembirakan sehingga diperlukan upaya terus menerus untuk dapat mencapai target yang diharapkan. Selain perbaikan pelayanan kepada masyarakat pemohon, sosialisasi kepada masyarakat luas mengenai administrasi kependudukan perlu terus dilakukan agar masyarakat memperoleh pemahaman yang benar mengenai administrasi kependudukan. Disamping itu, perbaikan dalam hal sarana prasarana maupun mutu SDM juga perlu dilakukan.

Faktor ekstern yang mempengaruhi kualitas pelayanan antara lain menurut Kepmen PANNo.63/KEP/M.PAN/7/2003 tentang Pedoman Umum Penyelenggaraan Pelayanan Publik. yaitu prosedur pelayanan, waktu penyelesaian, biaya pelayanan, produk pelayanan, sarana dan prasarana dan kompetensi petugas pelayanan, dalam penelitian ini biaya pelayanan dan produk pelayanan sudah termasuk dalam prosedur pelayanan sehingga yang meliput 4 (empat) faktor, yaitu :

1. Prosedur pelayanan

Prosedur pelayanan merupakan salah satu dari standar pelayanan publik. Prosedur pelayanan harus dibakukan bagi pemberi dan penerima pelayanan publik, termasuk pengaduan sehingga tidak terjadi permasalahan dikemudian hari. Prosedur pelayanan harus ditetapkan melalui standar operasional prosedur, sehingga pihak penerima pelayanan dapat memahami mekanismenya. Prosedur pelayanan tidak berbelit-belit dan mudah dipahami. Produk pelayanan yang dihasilkan dari pelayanan akan diterima masyarakat sesuai dengan ketentuan yang telah ditetapkan. Biaya pelayanan termasuk rinciannya harus ditentukan secara konsisten dan tidak boleh ada diskriminasi, sebab akan menimbulkan ketidakpercayaan penerima pelayanan kepada pemberi pelayanan. Biaya pelayanan ini harus jelas pada setiap jasa pelayanan yang akan diberikan kepada masyarakat, sehingga tidak menimbulkan kecemasan, khususnya kepada pihak atau masyarakat yang kurang mampu.

2. Waktu penyelesaian

Waktu penyelesaian yang ditetapkan sejak saat pengajuan permohonan sampai dengan penyelesaian pelayanan. Semakin cepat waktu penyelesaian pelayanan, maka akan semakin meningkatkan kepercayaan masyarakat akan pelayanan yang diberikan. Kepastian waktu pelayanan dapat diselesaikan dalam kurun waktu yang telah ditentukan.

3. Sarana dan Prasarana

Penyediaan sarana dan prasarana pelayanan yang memadai oleh penyelenggara pelayanan publik. Tersedianya sarana dan prasarana kerja, peralatan kerja dan pendukung lainnya termasuk penyediaan sarana teknologi komunikasi dan informatika (telematika). Lingkungan kerja yang tertib, teratur disediakan ruang tunggu yang memadai, bersih dan rapi. Lingkungan yang indah dan sehat serta dilengkapi dengan fasilitas pendukung pelayanan seperti tempat ibadah, parkir,toilet. 
4. Kompetensi petugas pemberi pelayanan

Kompetensi petugas pemberi pelayanan harus ditetapkan dengan tepat berdasarkan pengetahuan, keahlian, keterampilan, sikap, dan perilaku yang dibutuhkan.

Berdasarkan penjelasan diatas dapat di artikan bahwa dengan adanya standar pelayanan publik maka suatu pelayanan itu bisa berjalan sesuai dengan harapan dan dapat memberikan kepuasan dalam pelayanan kepada masyarakat.

Upaya untuk mewujudkan penyelenggaraan Pemerintahan secara benar termasuk didalamnya penyelenggaraan pelayanan publik memerlukan unsur-unsur mendasar antara lain adalah unsur profesionalitas dari pelaku dan penyelenggara pemerintahan dan pelayanan publik. Terabaikannya unsur profesionalitas dalam menjalankan tugas dan fungsi organisasi pemerintahan akan berdampak kepada menurunnya kualitas penyelenggaraan pemerintahan dan pelayanan publik. Sehingga aparatur dituntut untuk memiliki kemampuan dan keahlian untuk memahami aspirasi dan kebutuhan masyarakat kedalam kegiatan dan program pelayanan.

\section{PENUTUP}

Kesimpulan

Pada hasil penelitian ini, maka kesimpulan yang dikemukakan dari penelitian ini adalah sebagai berikut:

1. Pekerjaan selalu terhalangi dengan kurangnya pegawai

2. Dokumen masyarakat belum lengkap

3. Pegawai yang bekerja sebagian belum sesuai dengan kompetensi tetapi hanya berdasarkan pengalaman kerja

4. Saat tertentu terdapat sikap kompromi yang berdampak pada hasil kerja belum sesuai dengan apa yang diharapkan.

\section{Saran}

Berdasarkan kesimpulan Untuk itu disarankan sebaiknya:

1. Dilakukan perbaikan kualitas Sumber Daya Manusia

2. Pengadaan sarana prasarana untuk kepentingan pelayanan

3. Sosialisasi kepada masyarakat mengenai kelengkapan administrasi kependudukan yang harus disiapkan oleh masyarakat,

4. Ditingkatkan kemandirian

5. Ditingkatkan tanggung jawab ASN.

\section{DAFTAR PUSTAKA}

Kurniawan, Agung 2005. Transformasi Pelayanan Publik. Yokyakarta: Arus Media

M. Arifin. 2012. Strategi dan Pembelajaran Pendidikan Karakter. Yokyakarta Arus Media

Milles, M. B.and Huberman, M. A.1992. Qualitative Data Analysis. London: Sage Publikation.

Mulyadi. Deddy. 2015, Studi Kebijakan Publik dan Pelayanan Publik.Penerbit : Alfabeta. Bandung

Rasyid, Muhammad Ryaas. 1998.Desentralisasi Dalam Menunjang Pembangunan Daerah Dalam

Pembangunan Adminitrasi di Indonesia. Pustaka Lp3Es: Jakarta

Sobandi, Baban. 2002. Etika Kebijakan Publik, Jakarta: Mutiara Ilmu

Siagian. Sondang P. 2002. Filsafat Adminitrasi. Jakarta: PT. Bumi Aksara

Sembang. Riski. 2016. Profesionalitas Pelayanan Publik Aparatur Birokrasi Kantor Kecamatan Modoinding Kab Minahasa Selatan. UNIMA

\section{Regulasi}

Keputusan Menteri Pendayagunaan Aparatur Negara Nomor 63 Tahun 2003 tentang Pedoman Umum Penyelenggaraan Pelayanan Publik

Peraturan Bupati Kepulauan Sangihe Nomor 54 tahun 2016 tentang Kedudukan Susunan Organisasi, Tugas dan Fungsi Serta Tata Kerja Dinas Kependudukan dan Pencatatan Sipil Kabupaten Kepulauan Sangihe Peraturan Menteri

Pendayagunaan Aparatur Negara Dan Reformasi Birokrasi RI Nomor 15 tahun 2014 tentang Pedoman Standar Pelayanan. 
Undang-Undang Nomor 24 Tahun 2013 tentang perubahan atas Undang-UndangNomor 23 Tahun 2006 tentang administrasi kependudukan

Undang-Undang Nomor 25 Tahun 2009 tentang Pelayanan Publik.

Undang-Undang No 5 Tahun 2014 tentang Aparatur Sipil Negara.

Undang-Undang Nomor 43 Tahun 1999 tentang perubahanUndang-undang Nomor 8 Tahun 1974 tentang Pokok-Pokok Kepegawaian

\section{Sumber Internet}

http://www.neliti.com//id/publikations/1169/Profesionalisme-birokrasi-aparat-pemerintah-dalampelaksanaan-pelayanan-publik-dArtikel ejournal dila (08-16- 14-02-50-56).pdf Di Akses : 6 juli $2018 \mathrm{Pkl} 13.23$

http://ejournal.an.fisip-unmul.ac.id/site/wp-content/Di Akses : 6 Agustus 2018 Pkl 10.05

\section{Jurnal}

Theresia C. Tambayong. 2016. Profesionalisme Birokrasi Aparat Pemerintah dalam Pelaksanaan Pelayanan Publik Di Kecamatan Tomohon. Universitas Sam Ratulangi, Manado 